\title{
L'ecriture Feminine: A Study of Uzma Aslam Khan's Novel Thinner than Skin
}

\author{
* Asfandyar Shah, Lecturer (Corresponding Author) \\ ** Sajjad Ahmad, Lecturer \\ *** Umar Sajjad, Lecturer
}

\begin{abstract}
The present study focuses on feminine writing in the context of Pakistani English writings. This study aims to explain one of the main strands of feminism i.e. l'ecriture feminine which means feminine writing. The current study is based on the representation of l'ecriture feminine in Uzma Aslam Khan's novel, Thinner than Skin. The researcher has collected the data from the selected novel and made an in-depth analysis of the characters and scenes of this novel. Female body parts are pictured by the narrator at different points in the novel. Female characters remain the center of discussion in the selected narrative. It is identified from the discussion that all the major elements of L'ecriture feminine are portrayed in the text of the novel.
\end{abstract}

Keywords: Uzma Aslam Khan, L'ecriture Feminine, Pakistani English Writings.

Introduction

"Feminism is a belief and asserts that women should have equal liberties and opportunities as men" (Oxford Dictionary, n.d.). The word Feminism denotes the number of social, cultural, and political movements, theories, and moral philosophies concerned with gender inequalities and equal rights for women. The term "Feminism" originated from the French word "Feminisme" which was coined by utopian socialist Charles Fourier in 1837 and was first used in English in the 1890s in association with the movement for equal political and legal rights for women. Feminism concerns with issues such as women's independence, political rights, social freedom, economic independence, abortion and reproductive rights, divorce and putting end to domestic violence, gender stereotypes, discrimination, sexism, objectification, and prostitution. A Vindication of the Rights of Women written by Mary Wollstonecraft in 1742 is considered a germinal essay in feminism. Feminism is a theme is exploited by Jane Austen in Pride and Prejudice (1813) and Sense and Sensibility (1811) in the Victorian age. Pakistani English writer, Qaisra Shahraz (1958- ), also depicted feminism in her novel The Holy Woman (2001). Tehmina Durrani (1953- ) has done the same in My Feudal Lord (1991) while focusing on female sufferings.

If we look into the past time, we see that certain authors were writing about females of that age. Medea is an Ancient Greek tragedy written in 431 BC by Euripides. The plot centers on the conditions of Medea due to the second marriage of her husband. A Franciscan woman Christine De Pisan is considered to be the first feminist thinker in the $15^{\text {th }}$ century. In the $17^{\text {th }}$ century, some of the female writers also took part and played a very precious role in the West Indian Slave Rebellion Revolution. They were also part of the $18^{\text {th }}$ century French Revolution. From all these references we can judge that women have played an important role in all these revolutions in history. But in the latter part of the $18^{\text {th }}$ century, we can see that strict rules were made to control the different movements of feminism, females were only bound to their houses and household activities. "Feminism isn't about making women strong. Women are already strong. It's about changing the way the world perceives that strength" (G.D. Anderson)

There are different types of feminism like liberal feminism, radical feminism, individual feminism, black feminism, ecofeminism, and l'ecriture feminism. The term l'ecriture feminism was first used by Helene Cixous (1937- ), In the Laugh of the Medausa (1976) where she asserts that woman must write herself, must write about women, and bring women to writing, from which they have been driven away as violently as from their bodies. L'ecriture feminism is defined as "feminine

\footnotetext{
* Bacha Khan University, Charsadda Email: mommandshah@ gmail.com

** Department of English, Bacha Khan University, Charsadda Email: lecturerbkuc@gmail.com

*** Department of English, Bacha Khan University, Charsadda Email: umarsajjad.english@bkucedu.pk
} 
writing" or "women's writing". As a theory, it gives the importance of language to understand yourself. It helps women breaking the perception of themselves as a commodity in juxtaposing with men. Hence it helps them in the emergence of themselves as their own identity.

There is also a long history of South Asian feminist solidarity. From the 1980s onwards, feminists from India, Bangladesh, Pakistan, and Sri Lanka have been in intellectual conversation. They have politically come together and issued common statements in times of terrible conflict between the countries (Anwesha, 2013). Writers like Smita Agarwal, Anuja Chauhan, Tehmina Durrani, Fehmida Riaz, and Bapsi Sidhwa are strong representatives of feminism in South Asia. Amongst these writers, Uzma Aslam Khan is also a very influential feminist writer.

In this research L'ecriture, Feminism is highlighted in the novel Thinner than Skin (2012) written by Pakistani English writer, Uzma Aslam Khan who was born on $19^{\text {th }}$ Feb 1969 in the city of Lahore but grew up in Karachi. She was awarded the scholarship to proceed with her studies at Hobart and William Smith Colleges, New York. After completing her BA, she received an MFA from the University of Arizona, Tucson, United States.

The literary carrier of Khan is not complex, The Story of Noble Rot (2001), which was published by Penguin Books in 2001. Her second novel is Trespassing (2003), which has been translated into fourteen languages. Her third novel, The Geometry of God (2008), tells us the story of a young boy, Amal, who discovers the fossils of the dead Whale's ear. Thinner than Skin (2012) is her fourth novel.

"Thinner than Skin" is a story about love and identity and the novelist sets the setting of the novel among the beautiful places of Northern areas of Pakistan. Nadir is the narrator and the main character of the novel who is originally Pakistani but lives in America struggles and tries to make his carrier in photography. He decides to go to the beautiful landscapes of the Northern areas and make some photographs with his girlfriend Farhana. Then the readers are introduced to a Gujjar family. The main character of this family is Maryam, she has three children and her husband is handicapped. But she is loved by her old lover Ghafoor. We can see a connection building up between this Gujjar family and Nadir and Farhana. But there is a shift in the story when we see the death of a young girl who is the daughter of Maryam. The final destruction takes place when they are leading towards the glacier. At the end of the novel, Nadir hears news about a bomb blast in a hotel and the death of the few foreigners in the same hotel.

\section{Delimitation}

The current research is confined to the novel Thinner than Skin (2012), written by well-known feminist writer Uzma Aslam Khan. This novel is not only about L'ecriture feminism, but it also concentrates on belonging, identity, and the element of which takes place between Nadir and Farhana as highlighted in the novel. So, the current study is going to be delimited to the characters and events of the novel in the light of L'ecriture feminism.

\section{Research Objectives}

1) To focus on L'ecriture feminism in the context of Pakistani writers with a focus on Uzma Aslam khan's Thinner than Skin.

\section{Research Questions}

1) How does Uzma Aslam khan deal with L'ecriture feminism in Thinner than Skin?

\section{Significance of the study}

The importance of this study is that it will be helpful for the new researchers to understand and study the text in the light of L'ecriture feminism. This research is also going to open the doors of feminist psychology depicted by Pakistani female writers in their novels respectively. Moreover, this research would encourage the readers of today, tomorrow, and the days by going in every aspect.

\section{Literature Review}

Literature gives a portrait of life and society to reveal the facts of the world and the truths prevailing over here. The way a writer draft characters in a story, matters a lot as the qualities related to these characters become generalizations afterward and these characters are then always be viewed from that specified angle. The representation of a male character as a brave, courageous, bold, reserve, confident and rational being whereas that of a female character as a weak, expressive, shy, submissive, emotional, and irrational being; sets mind for gender discrimination and division of human characteristics into two separate categories. Because of this reason now we different female 
writers, supporting female characters in their novels. Especially when a female writer writes about women in her work then that work is called L'ecriture feminism or feminine writing.

One of the most effective theoretical concepts for women's writing and reading is the idea of

l'ecriture feminism. "As far as Females have already started to renovate not only the matter of the subject, but also the different other methods of generating meaning in fiction, visual art, poetry, and film. If we consider l'ecriture feminine as a utopian model, a stimulating myth rather than an idea for how all the women are asked to write or should write, concrete and theoretical difficulties rise again from an ideal which is well-defined in this manner" (jones, 1981). Madeleine Gagnon in La Venue an l'ecriture, written with Cixous states that, "women, unrestricted from the self-limiting economy of male libido have a larger naturalness in body and on the other hand on language as well" (1977).

Millard, Mills, and Pearce in their essay "French feminisms", say that "it was mainly a supposition that women subjects reserve a special association to the phase of development that headed to Cixous's theorization of l'ecriture feminine (Millard, Mills, Pearce)

Wuthering Heights (1847) is a literary piece that foresees L'ecriture feminine by relating it to L'ensorcelee, a novel that comprises a blazing and liberated but not particularly female lead" (Moody, 2003). "As compared to Jeanne's more undeviating desire we first perceive an indication of l'ecriture feminism in the multidirectional and melted quality of Catherine's wishes (Moody, 2003). L'ecriture feminism is depicted in "l'ensorcelee" when Jehoel bewitches Jeanne, who in rank has no sufferers. Other characters are under the effect of Jehoel's enchantment, but no one is seen affected by Jeanne. Nor is she allowed to fill her physical need for the abbe, however she surely attempts to do so. And even her incursions into the supernatural through the gypsy shepherds and their incantations are of no benefit. Ultimately she gets drowned in the lake's water quenching the flame which Jehoel kindled within her. Jeanne dies without the symbolic blood which is extremely important to her (Moody, 2003). Lachover (2013) highlighted that radical feminism was aroused in the countries. Radical feminism emphasizes the subjugation of females.

Helene Cixous is a French literary critic and writer. She is a feminist and her stories are mainly based on themes of feminism. She coined the term l'ecriture feminine. It means work importantly to distress the idea of narrative, language, form, 'order, organization. Female writers like Helene Cixous emphasis on woman body" (Shalini, 2014)

Vachhani (2018) explored the politics of writing differently for teaching, researching, and discourses about organizations. It also highlighted the indispensability of exposing the effects of masculinity in text: writing and speaking. Furthermore, it has explored suppress and hidden possibilities but also offers chances to claim space for an affective feminist politics engraved in language.

According to Zeiny (2019), the emphasis on the new language is because women cannot voice their plights, emotions, and concerns in a male dominant language which echoes insufficient to their expressive needs. It would put the relevant ideas again in a position of linguistically targeted, silent, or dominant in language and social signification. The only way to rout the masculine suppression is to generate a language not subjugated by the phallus.

L'ecriture feminism has been highlighted in Eavan Boland's In Her Image (1980) which discovers the terrifying interiority, hazardous misunderstanding, and backward psychological progress of a female speaker who strangles her child. This poem "makes some more powerful and modest rights for feminist art, especially aesthetic, unveiling its ancestor. In Her Image (1980) marks a phase of an experimental way of writing for Boland, a focused and attentive experiment which is now commonly denoted as l'ecriture feminine, writing situated in and approved by essential female knowledge and skills(Randolph, 1991). "In her poetry Boland enhance different ways of women experience that are not given much value by exposing to public opinion which has been ignored by her society and culture" (Randolph, 1991).

L'ecriture feminine thus strives to be a style of writing idiosyncratically female and authorized to raise mother and daughter in possession of their own to the rank of the subject (Ordonez, 1987). Reiner (2008) has addressed issues like matrimony, family law, and equality at the workplace.

Different philosophical perspectives, practices, and beliefs encourage both human concern and that kind of society that is desired by the individuals. Karl Marx (1818-1883) has suggested that 'free development of each is the condition for the free development of all' (Slott, 2011). Kindersley 
and Sarah Vine (2009) state that it is very difficult for a female to survive in this society, not only in the social life but to work in the field of writing seems to be an impossible art for them (Kindersley, 2009).

According to Enslin and Tjiattas (2004), existing cultural setup and norms supports men's control of women and able to socialize and naturalize these established norms into unquestioning acceptance. Marie Mullins in her article Leaves of Grass as a Women's Book depicts the cries and every aspect of women's situation. She tries to polish the strength of women and clearly says that this book is written by a woman therefore it is a women's book that completely portrays a woman. In review to this book Walt Whitman made his remark "I am the poet of the woman the same as the man" (Mullins, 1994)

Antonopoulus (1991) says that females are now emerging to develop textual alternatives and participate in the field of literature. (Antonopoulus, 1991). According to Yanay-Ventura and Yanay (2016) that the field of feministic studies is a challenging, active, and important area of research for social welfare. Sohelia Ghaussy (1994) articulates that how feminine writing or l'ecriture feminism can be used in foreign politics who use all these feminist strategies. How l'ecriture feminism connects itself with the women of society and reflects the lives of women from different cultures.

Brionylipton (2015) argued that Cixous invites women to reclaim their sexuality and subjectivity via feminine writing. Furthermore, she has defined l'ecriture feminine: it can be understood as a liberating bodily practice that aims to release women's suppressed creative agency and change the phallocentric structure. This study focuses on L'ecriture feminism depicted in the novel Thinner than Skin (2012) by Uzma Aslam Khan. It is highlighted through the detailed study of characters and scenes.

\section{Research Methodology \\ Research Design}

The research has been carried out by following a qualitative approach, where the characters, events, and incidents of the novel have been discussed and described by following the elements of L'ecriture feminism.

\section{Research Method}

The research is mainly based on the relevant extracts from the text of the novel and thematic analysis and is descriptive. Where the characters of the novel are described by following the theory of L'ecriture feminine.

\section{Theoretical Framework}

The researcher has followed the theory of L'ecriture Feminism, suggested by well-known French female writer Helene Cixous. She has mentioned this word for the first time in one of her works In the Laugh of Medusa in 1976. The English meaning of L'ecriture feminine is woman's writing. In the broader interpretation of the theory, it contains different approaches towards writing style. It is an artistic ability of the writer to portray the actual concept of women in society. In addition to that, this theory specifically inclines towards western society, where women were treated as inferior and weaker as compared to men. They were considered as unable to produce any kind of art, even in the world of literature they were always pushed back to their homes. Therefore, this theory illustrates an opinion of western people about women and then suggests her brilliant thoughts to change such kinds of thoughts about women in western society.

She believes that women can change their social status as an individual or a group of people through the art of writing, which asserts that she encourages women to write to achieve their position in society. Correspondingly. She explains the importance of language, which has always been used as a weapon to articulate the status of anybody. Furthermore, she opines that the relationship between men and women in a relationship of power and dominance. Therefore, they are being treated as marginalized people in the society, man is always considered as a superior who decides the social status of women. This theory widely encourages and enhances the ability of women to achieve their social status in society through writings. Apart from it, this theory encourages every individual woman to write for their own sake and the sake of every other suppressed woman.

According to a famous psychologist Sigmund Freud that the language is men-centered, which demonstrates the dominant approach of men over women while Helene Cixous does not support the idea of Freud by saying that this concept has been created by men to make women downward. She illustrates the significance of women through their body and sexuality which is an honor and most 
powerful passion to get their status in the society by rejecting male dominant thinking. This theory contains constitutive notions and elements. The author of the work must be female. There shall be a description of the female body parts. There shall be some sensual scenes. The female characters shall be more strong and important than the male characters.

In the same way, the same kinds of ideas and elements have been found out in the novel, which has been widely used by Helen Cixous in her theory of L'ecriture feminism. The researcher has adopted some particular elements of the theory which are also shown in the novel Thinner than Skin.

\section{Content Analysis}

The theory of L'ecriture feminine is mainly based on few elements and critically analyzes and discusses the text of the novel Thinner than Skin by Uzma Aslam Khan. It is observed that these important elements of L'ecriture feminine are depicted in this novel by the author of Thinner than Skin (2012). Some of the elements of L'ecriture Feminine are that the author of the novel must be female. There shall be some sensual scenes. There shall be a description of the female body parts and the female characters of the novel are mostly stronger

The first part of the analysis which needs to be discussed is about the author of the novel, who is female. The name of the author is Uzma Aslam khan who was born in Lahore and then shifted to America. Her debut novel is The Story of a Noble Rot (2001). There are also some other novels like The Geometry of God (2008) and Trespassing (2003) that are written by her and these novels are very praised by the readers and critics across Pakistan. Uzma Aslam Khan is very clearly depicting L'ecriture Feminine in her novel thinner than Skin (2012) through the characters and in different scenes of the novel. But the novel is not written in the female voice and the narrator of the story is a male whose name is Nadir. She uses the first-person narrative in a male voice. By reading this novel one can easily observe that the author is having complete knowledge of the northern areas of Pakistan. She gives complete detail about the people that live in this area and very smartly moves the love story of Nadir and Farhana with the Gujjar family of the northern areas.

The second aspect of the novel is that time and again sensual scenes are added to the story which is one of the vital elements of L'ecriture feminine. The main characters of the novel Nadir and Farhana are mostly seen in the sensual scenes. They love each other and without having the knots of marriage they are often seen making love with one another. At the very start of the novel while coming back to the cabin Nadir narrates that he finally got back to the cabin having no clothes, moved himself to the bed where Farhana was laying, she made someplace for him and he felt the heat radiated from her body in sheets of the bed. He bent me at her back and she turned back to him presenting him the gift which she gave to Nadir on the first night of their love. She moved her finger near his navel. The hair of Farhana was spread across his lower body and she was blowing out her very sweet breath over his skin which was very cold. And when he was enclosed in her lips he thought it bliss and was thinking that today he was not making with her but she was making with him. "Her lips enclosed me, I thought, Bliss!" (Khan, 2012, p. 14).

Nadir says that when they were in Kaghan, it was a morning time Farhana was still sleeping and he watched her very thoroughly. He brought his mouth closer to her lips and tasted her very sweet morning breath. He felt the fleshiness of Farhana's lips with the tip of his nose. She was not wearing lipstick and he liked it "because her naked mouth blended beautifully with the rest of her" (khan, 2012, p. 18). For the first time they meet at the Golden Gate Bridge while talking to her he observes that Farhana is wearing no bra beneath her T-shirt. And she also tells him that she would have made her body naked for him but she doesn't have any breasts. Nadir focuses on the physical appearance of Farhana and also notices that how her braid is wrapped around her shoulder. He calls her a "calla lily" which is a white and yellowish flower. Then suddenly she bows her head, turning her back to Nadir and takes her shirt off, and says to him that she will meet him tomorrow.

Further in chapter two, these two lovers photograph themselves in turns and after taking pictures of their naked bodies. "I photograph a series of black and white prints as lay on her side, legs in dark sheets, muscles bright as planets" (khan, 2012, p. 96) In the meanwhile Nadir refers to a book The Male and The Female Figure in a motion which is a story of a naked woman and man who are engaged in different activities. He compares themselves with that couple and says that for their version it was a bit different because instead of hankies which they were throwing above their shoulders they were throwing dirty underwear. They opened three bottles of wine, but only drinking 
two and wasting the other one. "By evening, after making love once and trying again without success, we collapsed, naked and in love" (khan, 2012, p. 97). These two lovers are seen in making love and their lovemaking is described by the author by using such words which makes it very vivid for the readers to grasp it. And another thing is that both of these young characters belong to Pakistan but now they are citizens of the United States of America where such relationships are not opposed by society before marriage.

The third point of the analysis is that at many stages female body parts are vividly depicted by the author. This is also one of the elements of feminine writing that the female body parts are presented by the writer. Uzma Aslam khan tries to make the imagery very vivid by presenting the body parts of Farhana to the readers in the narration of Nadir. In the first chapter of the novel we see that Farhana and Nadir are laying in the bed, she is asleep but Nadir is awake. He describes the combination of her lips and mouth with the other parts of the body. He says that she very rarely wore lipstick and for this, he was very thankful because her naked mouth was in a good combination with the rest of her body.

Further in chapter two the author deals with the body parts of her female character more vividly and depicts her body parts when Nadir and Farhana were in a room all alone. Nadir states that he asked Farhana that can he photograph her legs. Her legs were such that stole his soul. And then she undressed her body for Nadir. It was the same looks on her that he saw on her face when she undressed for the first time on that night. While she was lying on her side and her legs were in dark sheets he shot some pictures of black and white prints. The muscles of her legs were "as bright as planets" (khan, 2012, p. 96). Her legs were steep which were built by steepness, mountain legs indeed. The calves and ankles tapered tidily to each other very sturdy and sloping. And when they were in bed she bent her body and shot her ass but all of a sudden she took the camera and pictured his body parts.

The author moves the love story of Farhana and Nadir in the novel with their arrival in the northern areas of Pakistan and their introduction to the Gujjar family. But at different intervals, she places the elements of Feminine writing with the story of the novel in a very beautiful manner. She has the character of Nadir by whom she describes the body parts of Farhana and we also see them making love with each other at different points. Nadir is a photographer and he photographs her body parts.

The reader observes him saying that he bought a new camera and he was supposed to have pictures of his girlfriend's magnified nipples and the blurry outlines of her breast made him more anxious than she ever did in the whole time they have spent together. On phone, they always talked about her work, her return, and her anxiety about the return. They not only talked about these things but also about her breasts. Farhana liked Nadir to photograph them with his camera lens. Those breasts had started to stir Nadir only in the pictures. And on that day on the beach when she lay down on her stomach, setting her hair with her finger, he saw her legs moving around one another, and then he sprinkled down some sand on the round of her buttocks. It dropped upon the curves of her body and matched with the color of her skin tone. And when he took the camera back and view the pictures of the past days he saw some pictures of Farhana with silent backgrounds and magnified nipple. "Her breasts. She liked me photographing them" (khan, 2012, pp. 174-175).

The idea behind these sensual scenes and depiction of the female body parts is not only to show the love between Farhana and Nadir but the author makes this text feminine writing by adding these elements to the story. There are some other things as well, which are under the keen focus of the author. One can have the idea about the people of Pakistan living amongst the mountains full of dark green trees that are shrouded by the snow and moved by the cold wind in summers. Different lakes and glaciers which are world-famous are described by her in a really good manner.

The fourth point which needs to be discussed is the characters of the novel. By dividing the characters of the novel into two groups, male and female characters, then we can realize that the female characters are more strongly presented by the author than the male characters. The first female character introduced by the author is Farhana, who is sensuous and courageous like the other characters, Mehwish in The Geometry of God (2008) and Dia in Trespassing (2003). She lives in America with her father but moves to the northern areas of her native country with his boyfriend whose name is Nadir. He has come here to make his carrier in Photography by taking pictures of the beautiful glaciers of these areas. They have other two friends Wes and Irfan. Wes is Farhana's old 
friend, who has also come with them to visit Pakistan. And Irfan is an old friend of Nadir who lives in Karachi (khan, 2012, p. 21). Irfan joins them because all of them are new in Pakistan and they don't know about this country. There are other two important female characters, Maryam and Kiran. Kiran is a little young girl, she is Maryam's daughter. The introductory lines to her appearance say that there were some spots of dirt on her cheek and her front teeth were missing which shows her age, which means she is below ten years. Nadir says that he could hear a cough that was wet and rattling. Her neck was surrounded by some heavy necklaces and her wrists were enchained by the beautiful bracelets. The remarks of Farhana about this little girl are very positive because she says that this girl is beautiful and she would be more beautiful if she were received some good care. "Around her neck were heavy necklaces and her wrists were encased in even heavier bracelets" (khan, 2012, p. 66). Maryam is a middle-aged woman, who is the mother of Kiran and other two children, belongs to a Gujjar family. She is married to a man who is handicapped but loved by her old lover, Ghafoor. He tells her about the stories of his travels to the neighboring countries. She knew about all the stories about the mountains and the legends of these mountains but she is more interested in the stories beyond these mountains. "Maryam was more interested in the stories from beyond the mountains than the stuff of legend" (khan, 2012, p. 85)

Following are the main characters of the novel but the important characters amongst these are the female characters. Because all the main events are dominated by the female characters. Farhana is the most important one because her sensuality and the description of her body parts make this novel feminine writing. From the tragic incidence of Kiran's death, we can analyze the importance of the female characters in the story of the novel. Almost the entire story revolves around the female characters whether it's the love story of Farhana and Nadir or the tragic incident of the drowning of Kiran in the lake. Her death turns the story the other way.

So, after analyzing the text of the novel all these elements of feminine writing or L'ecriture feminine are very clearly depicted by the author. Uzma Aslam Khan is a very smart writer and she follows the relationship of Farhana and Nadir and through these characters, she conveys her message.

\section{Conclusion}

In the light of the detailed study of the novel thinner than Skin, the researcher has concluded that this novel can be termed as feminine writing. As it is clear from the above discussion that all the major elements of the theory of L'ecriture feminism are present in the text of the novel. Uzma Aslam Khan has very vividly presented the elements of this theory in the novel. As we can see the description of female body parts in the narration of Nadir. The body parts of Farhana are described by the author at different parts of the novel. Not only this but some sensual scenes are also portrayed amongst the two main characters of the story. It is also one of the main elements of this theory. The female characters are also stronger in the story of the novel. Mostly the story moves around the female characters, especially Farhana and Kiran. The author of the novel is also a woman. So, all these elements of the theory are very clearly presented in the novel due to which this text can be named as feminine writing.

\section{References}

Allen-Randolph J. (n.d.). L'ecriture Feminine and the Authorship of Self in Eavan Boland's In Her Image. (C. Quarterly, Ed.) 1, 8.

Antonopoulus, A. (1991). writing the mystic body.

Jones, Ann Rosalind. (1981). "Writing the Body: Toward an Understanding of L'ecriture Feminine". Feminist Studies 7, 2, 247-263.

khan. (2012). Thinner than Skin.

Lachover, E. (2013). "Influential Women: Feminist Discourse in women's business". Communication, culture, and critique.

Lipton. B (2015). Writing through the labyrinth: Using l'ecriture feminine in leadership studies. SAGE, journals

Liu, p. (2007). "Queer Marxism in Taiwan". Inter-cultural Asia Studies.

Millard, Mills, Pearce. (n.d.). French Feminism.

Moody, Kathryn Irene. (2003). " A Twice-Told Gothic Romance: The Anatomical Difference In Jules Barbey D'aurevilly's L'ensorcelee and Emily Bronte's Wuthering Heights".

Mullins, M. (1994). Leaves of Grass as a Women's Book. 
Ordonez, Elizabeth J. (1987). "Inscribing Difference: L'ecriture Feminine and New Narrative by Women". Anales de la literarura espanola contemporanea. Society of Spanish and SpanishAmerican Studies.

Reiner. T (2008) "The Philosophical foundation of gender equality in liberalism and Marxism: a study of Mill and Marx. Journal of Academy of social sciences.

Taina Kindersley, S. V. (2017.). "Backwards in High Heels" The Impossible Art of Being Female.

Vachhani. S.J. (2018) "Rethinking the politics of writing differently through ecriture feminine" SAGE, journals.

Yanay. V and Yanay. (2016) "unhyphenated Jewish religious feminism women studies international forum. University Press

Zeini. E. (2019). "Ecriture Feminine: Feminism and Nationalism in Syyedeh Hosseini's 'One Women's war: Da. IKMAS UKM Press. 